\title{
BAHAN AJAR BERBASIS MODEL QUANTUM TEACHING UNTUK MENINGKATKAN KEMAMPUAN BERPIKIR KRITIS
}

\author{
Nana Sutarna \\ Program Studi PGSD STKIP Muhammadiyah Kuningan \\ Jl. Moertasiah Soepomo No 28 B Cigugur - Kuningan, 45511 \\ E-mail: nana@upmk.ac.id \\ Nunu Nurfirdaus \\ Program Studi PGSD STKIP Muhammadiyah Kuningan \\ Jl. Moertasiah Soepomo No 28 B Cigugur - Kuningan, 45511 \\ E-mail: nunu@upmk.ac.id
}

\begin{abstract}
This study aims to describe the effect of quantum teaching model-based teaching materials on critical thinking skills of elementary school students. This type of research is development research using a model developed by Borg and Gall. Teaching Material Development starts from the preliminary study phase, planning, product design, product design validation, product trial and final product. The research instruments used consisted of validation sheets, sheets, questionnaires for analyzing student needs, cognitive tests, and tests of critical thinking skills. The research subjects were students in Class V of SDN 1 Cengal, SDN 2 Cengal and SDN 3 Cengal, Japara District, Kuningan Regency. The results showed that there was an increase in students' critical thinking skills using quantum teaching model-based teaching materials compared to students using conventional learning. The difference in this increase can be seen in the results of the gain test of students' critical thinking abilities in the experimental class showing N-gain of 0.59 . Then the N-gain in the experimental class is included in the criteria of being. It can be concluded that the use of teaching materials based on quantum teaching models can improve the critical thinking skills of elementary school students.
\end{abstract}

Keywords:

Teaching materials, quantum teaching model, critical thinking skills ability

\begin{abstract}
Abstrak
Penelitian ini bertujuan untuk mendeskripsikan pengaruh bahan ajar berbasis model quantum teaching terhadap kemampuan berpikir kritis siswa sekolah dasar. Jenis penelitian ini adalah penelitian pengembangan (Development Research) dengan menggunakan model yang dikembangkan oleh Borg and Gall. Pengembangan Bahan Ajar dimulai dari tahap studi pendahuluan, perencanaan, desain produk, validasi desain produk, uji coba produk dan produk akhir. Instrumen penelitian yang digunakan terdiri dari lembar validasi, lembar, angket analisis kebutuhan siswa, tes kognitif, dan tes kemampuan berpikir kritis. Subjek uji coba penelitian yaitu siswa Kelas V SDN 1 Cengal, SDN 2 Cengal dan SDN 3 Cengal Kecamatan Japara Kabupaten Kuningan. Hasil penelitian menunjukkan bahwa terdapat peningkatan kemampuan berpikir kritis siswa yang menggunakan bahan ajar berbasis model quantum teaching dibandingkan dengan siswa yang menggunakan pembelajaran konvensional. Perbedaan peningkatan ini dapat dilihat pada hasil uji gain kemampuan berpikir kritis siswa pada kelas eksperimen menunjukkan N-gain sebesar 0,59. Maka N-gain pada kelas eksperimen termasuk ke dalam kriteria sedang. Dapat disimpulkan bahwa penggunaan bahan ajar berbasis model quantum teaching dapat meningkatkan kemampuan berpikir kritis siswa sekolah dasar.
\end{abstract}

Kata Kunci:

Bahan ajar, Model quantum teaching, Kemampuan berpikir kritis 


\section{B. PENDAHULUAN}

Dunia sedang menghadapi era revolusi industri 4.0. Kondisi tersebut perlu mendapat perhatian dari seluruh kalangan dikarenakan akan sangat berdampak pada semua elemen kehidupan termasuk bidang pendidikan. Ada beberapa keterampilan yang dibutuhkan dalam dunia kerja di masa depan, salah satunya adalah keterampilan berpikir tingkat tinggi. Nugraha (2018:120) mengemukakan ada empat kategori berpikir tingkat tinggi yakni pemecahan masalah (problem solving), pengambilan keputusan (decision making), berpikir kritis (critical thinking), dan berpikir kreatif (creative thinking).

Hartini (2017:7) mengatakan bahwa kemampuan berpikir kritis merupakan salah satu kompetensi yang harus dikembangkan dan dilatihkan pada siswa melalui kegiatan pembelajaran, sehingga kemampuan tersebut terus tumbuh dan berkembang karena kemampuan ini sangat penting dalam berbagai aspek kehidupan. Hughes (2014: 30) juga mengemukakan bahwa selama 25 tahun terakhir, berpikir kritis telah ditegakkan sebagai salah satu keterampilan berpikir yang paling penting dalam pendidikan. Tidak hanya itu, Kettler (2014: 127) menyatakan bahwa 46 dari 50 negara bagian di AS, berkomitmen untuk mengembangkan kemampuan berpikir kritis siswa pada jenjang sekolah dasar.

Berpikir kritis adalah kegiatan disiplin mental dalam memecahkan masalah, mengambil keputusan, menganalisis asumsi, dan belajar konsep-konsep baru. Pengambilan keputusan yang rasional dapat memberikan kepercayaan dalam tindakan yang telah dilakukan.

Pendapat senada dikatakan oleh Amalia (2016:525) yang mengatakan bahwa berpikir kritis merupakan proses berpikir yang berlandaskan pada gagasan dan pemikiran dalam mengemukakan alasan untuk menyimpulkan dan menyelesaikan masalah.

Karakteristik berpikir kritis menurut Filsaime (2008: 81) melibatkan berbagai kemampuan diantaranya adalah: (a) Mengajukan berbagai pertanyaan; (b) Mengidentifikasi masalah; (c) Menguji fakta-fakta; (d) Menganalisis asumsi dan bias; (e) Menghindari penalaran emosional; (f) Menghindari over simplifikasi; (g) Mempertimbangkan interpretasi lain; dan (h) Mentoleransi ambiguitas.

Mengingat pentingnya kemampuan berpikir kritis, perlu didorong peningkatan kemampuan siswa melalui model pembelajaran yang efektif. Model quantum teaching dapat menjadi salah satu alternatif untuk digunakan. Rahayu (2014:133) berpendapat bahwa quantum teaching merupakan model pembelajaran yang dapat memfasilitasi siswa untuk menemukan konsep sendiri melalui pengalaman yang bermakna. Lebih lanjut Khairani (2016:13) menganalogikan quantum teaching sebagai orkestrasi, dimana bermacam-macam interaksi yang ada di dalam dan di sekitar momen belajar. Interaksi-interaksi ini mencakup unsur-unsur untuk belajar efektif yang mempengaruhi kesuksesan siswa.

Pakar yang mencetuskan teori ini, Deporter (2011:32) mengatakan bahwa quantum teaching adalah metodologi pembelajaran yang digunakan oleh guru untuk merancang dan menyajikan proses belajar yang menarik dengan melibatkan unsur-unsur yang mempengaruhi kesuksesan siswa dalam belajar serta berfokus pada hubungan dinamis dalam lingkungan kelas. Unsur-unsur yang dimaksud diantaranya kemampuan siswa untuk berpikir secara kritis mengenai sesuatu hal yang terjadi dalam pembelajaran yang meliputi cara memecahkan masalah, cara mengambil keputusan, menganalisis pendapat dan belajar dengan konsep-konsep baru.

Suparmono (2016:80) dalam penelitiannya mengungkapkan bahwa landasan utama dalam pembelajaran quantum adalah membawa dunia peserta didik ke dunia pendidik dan mengantarkan dunia peserta didik ke dunia pendidik sehingga mengisyaratkan pentingnya seorang pendidik memasuki dunia atau kehidupan peserta didik sebagai langkah awal dalam melaksanakan pembelajaran. Peran guru sebagai pendidik menjadi peran sentral, sebagaimana pendapat Hendrawan (2016:73) salah satu faktor yang mempengaruhi proses pembelajaran terdiri dari faktor internal dan eksternal. Faktor internal yang dimaksud adalah faktor-faktor yang berkaitan dengan pribadi guru.

Pembelajaran dengan model quantum teaching memiliki strategi melalui istilah "TANDUR", yaitu: Tumbuhkan, Alami, Namai, Demonstrasikan, Ulangi dan Rayakan (Yahya:2017:159). Strategi pembelajaran quantum teaching tersebut dapat dipaparkan sebagai berikut: (1) Tumbuhkan, yaitu dengan 
memberikan apersepsi yang cukup sehingga sejak awal kegiatan siswa termotivasi dan berminat untuk belajar dan memahami Apa Manfaatnya Bagiku (AMBAK); (2) Alami, berikan pengalaman nyata kepada setiap siswa untuk mencoba seluruh aktivitas dan momen belajar. Ciptakan atau datangkan pengalaman umum yang dapat dimengerti oleh semua siswa; (3) Namai, sediakan kata kunci, konsep, model, rumus, strategi atas pengalaman yang telah diperoleh siswa. Penamaan dapat memuaskan hasrat alami otak untuk memberikan identitas, mengurutkan, dan mendefinisikan. Penamaan adalah momen yang tepat untuk mengajarkan konsep dan keterampilan berpikir dan strategi belajar; (4) Demonstrasikan, guru memberi kesempatan kepada siswa untuk menunjukan kemampuannya. Tahap demonstrasi bisa dilakukan dengan penyajian di depan kelas, menjawab pertanyaan dan menunjukkan hasil pekerjaan; (5) Ulangi, beri kesempatan kepada siswa untuk mengulangi apa yang telah mereka pelajari, sehingga setiap siswa merasakan langsung di mana kesulitan yang mereka alami; dan (6) Rayakan, dimaksudkan sebagai respon pengakuan yang proporsional. Jika layak untuk dipelajari, maka layak pula untuk dirayakan. Merayakan akan memberikan rasa puas, senang terhadap apa yang telah dilakukan, perayaan bisa dilakukan dengan pujian, tepuk tangan dan bernyanyi bersama.

Penelitian ini berfokus pada pembuatan bahan ajar berbasis model quantum teaching sebagai upaya peningkatan kemampuan berpikir siswa. Oleh karenanya, langkah-langkah dan tahapan pembuatan bahan ajar perlu menjadi perhatian. Hal tersebut sesuai dengan pernyataan Yasintus Tinja dalam penelitiannya (2017:1258) bahwa buku yang dikembangkan harus dapat mendukung proses pembelajaran dan menampilkan keutuhan kompetensi yang akan dikuasai oleh peserta didik dalam kegiatan pembelajaran, sehingga peserta didik dapat menguasai suatu kompetensi secara utuh.

Kebutuhan mengenai penggunaan bahan ajar menjadi sesuatu hal yang penting. Sesuai dengan pendapat yang disampaikan Peritasari (2018:278) bahwa dalam penerapan pembelajaran tematik di sekolah dasar menuntut tersedianya bahan ajar yang memadai dan dapat digunakan untuk memenuhi kebutuhan pembelajaran yang terintegrasi antar satu mata pelajaran dengan pelajaran lainnya, bahkan dengan kehidupan siswa sehari-hari. Sedangkan langkah-langkah yang harus ditempuh dalam penyusunan bahan ajar adalah studi pendahuluan, perencanaan,desain produk, validasi desain produk, uji coba produk dan penyempurnaan produk akhir (Wibowo, 2017:745).

Dari paparan di atas diketahui bahwa tujuan penelitian ini adalah untuk mengetahui pengaruh penggunaan bahan ajar berbasis model quantum teaching terhadap kemampuan berpikir kritis siswa sekolah dasar.

\section{METODE PENELITIAN}

Tujuan dari penelitian ini adalah menghasilkan bahan ajar yang teruji keefektifannya untuk diterapkan pada proses pembelajaran di sekolah dasar. Pengembangan produk bahan ajar berbasis model quantum Teaching didasarkan pada modifikasi dari prosedur Borg \& Gall (Sugiyono, 2010). Adapun langkah-langkah dari model penelitian pengembangan adalah sebagai berikut:

1. Studi Pendahuluan

Penelitian ini berangkat dari adanya potensi masalah atau masalah. Semua masalah yang muncul diidentifikasi. Pada tahap ini juga dilakukan studi literatur dan pengumpulan informasi.

2. Perencanaan

Tahap perencanaan terdiri dari memilih desain berdasarkan analisis kebutuhan sehingga produk yang akan dihasilkan benar-benar sesuai dan dibutuhkan dalam pembelajaran. Kemudian dilanjutkan dengan menyusun draft bahan ajar dan membuat instrumen kelayakan produk.

\section{Desain Produk}

Pada tahap ini membuat desain produk bahan ajar berbasis model quantum teaching. 4. Validasi Desain Produk

Berisi tinjauan kepada ahli materi/isi dan ahli bahan ajar kemudian dilanjutkan dengan proses revisi produk awal.

5. Uji Coba Produk

Uji Coba produk dilakukan untuk mengetahui kualitas dan keefektifan produk yang telah dibuat sehingga dapat diketahui hal apa saja yang harus diperbaiki/disempurnakan.

6. Produk Akhir produk.

Hasil dari rangkaian proses pembuatan

Desain produk yang telah dibuat yakni berupa bahan ajar berbasis model quantum 
teaching harus diujicobakan penggunaanya pada kelompok terbatas dengan tujuan mendapatkan informasi apakah produk bahan ajar yang dibuat tersebut lebih efektif dan efisien dibandingkan dengan bahan ajar yang telah ada sebelumnya.

Untuk mencapai hal tersebut maka digunakan metode penelitian eksperimen kuasi (Quasi Experimental Design) dengan the nonrandomized control group, pretest-posttest. Creswell (2012, hlm. 307) mengemukakan bahwa dalam sebuah penelitian eksperimen, peneliti menguji sebuah ide atau gagasan (baik praktek maupun prosedur) untuk menentukan apakah hal yang diujikan tersebut mempengaruhi hasil atau variabel terikat.

Ary dkk (2010:316) menyebut bahwa the nonrandomized control group, pretest-posttest adalah salah satu desain yang paling banyak digunakan dalam metode penelitian eksperimen kuasi dalam pendidikan. Peneliti dalam desain nonrandomized control group, pretest-posttest menentukan kelompok eksperimen (O1) dan kelompok kontrol (O2), melakukan protes untuk kedua kelompok dengan maksud untuk mengetahui homogenitas dan normalitas kedua kelompok, melakukan perlakuan eksperimen (X) yang dalam penelitian ini adalah bahan ajar berbasis model quantum teaching berbantuan lectora inspire hanya dengan kelompok eksperimen (O1), dan kemudian melakukan pascates untuk mengukur perbedaan antara dua kelompok. Desain penelitian digambarkan dalam tabel sebagai berikut.

Tabel 1. Desain Kuasi Eksperimen

\begin{tabular}{|c|c|c|c|}
\hline Kelompok & Pretes & $\begin{array}{c}\text { Variabel } \\
\text { bebas }\end{array}$ & Postes \\
\hline Eksperimen & O1 & $\mathrm{X} 1$ & $\mathrm{O} 2$ \\
\hline Kontrol & $\mathrm{O} 3$ & $\mathrm{X} 2$ & $\mathrm{O} 4$ \\
\hline
\end{tabular}

(diadaptasi dari Ary, 2010)

Keterangan:

$\mathrm{O}_{1}$ : Tes awal pada kelompok eksperimen

$\mathrm{O}_{2}$ : Tes akhir pada kelompok eksperimen

$\mathrm{O}_{3}$ : Tes awal pada kelompok kontrol

$\mathrm{O}_{4}$ : Tes akhir pada kelompok kontrol

$\mathrm{X}_{1}$ : Pemberian perlakukan, bahan ajar berbasis model quantum teaching

$\mathrm{X}_{2}$ :Pemberian perlakuan dengan metode
Alur dari desain penelitian dapat dilihat pada gambar di bawah ini.

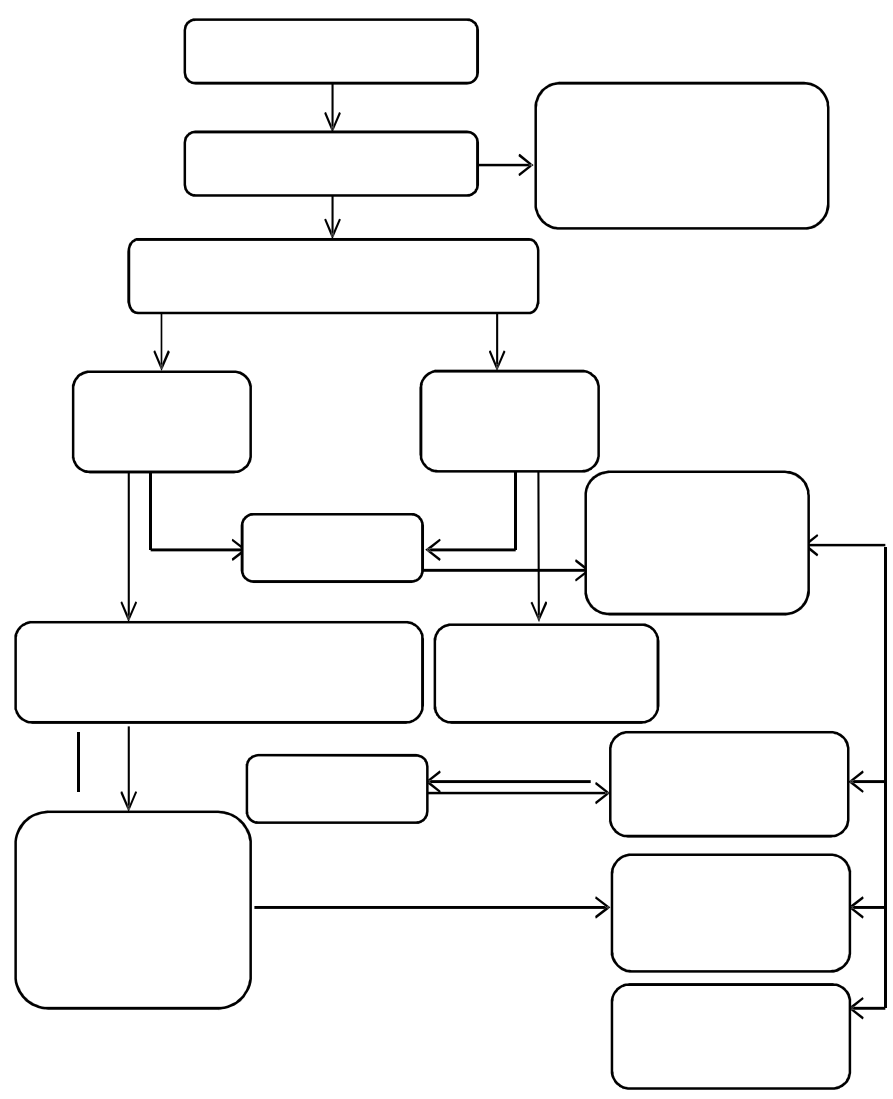

Gambar 1. Alur Penelitian

Pengambilan sampel pada penelitian ini menggunakan teknik purposive sampling. subjek penelitian ini terdiri dari tiga sekolah dasar yakni SDN 1 Cengal (sebagai kelas eksperimen dengan jumlah 37 siswa), SDN 2 Cengal (sebagai kelas kontrol dengan jumlah 37 siswa) dan SDN 3 Cengal (sebagai kelas uji coba produk berjumlah 24 siswa).

Instrumen dalam penelitian ini dibedakan menjadi instrumen pembelajaran dan instrumen pengumpul data. Instrumen pembelajaran terdiri dari bahan ajar yang dikembangkan berbasis model quantum teaching berupa buku bahan ajar siswa. Sedangkan instrumen pengumpul data berupa lembar observasi kegiatan guru dan peserta didik, lembar wawancara, dan lembar tes untuk mengukur kemampuan berpikir kritis.

Berdasarkan data yang diperoleh dalam penelitian ini yakni data kualitatif dan kuantitatif maka teknik yang akan digunakan untuk menganalisis data kualitatif adalah analisis secara deskriptif. Analisis deskriptif ini digunakan untuk mengetahui dan memperoleh 
gambaran mengenai efektivitas bahan ajar berbasis Model Quantum Teaching.

Sementara itu, teknik analisis data kuantitatif digunakan untuk menjawab hipotesis penelitian yang berkaitan dengan perbedaan kemampuan antara pembelajaran yang menggunakan bahan ajar berbasis model Quantum Teaching dibandingkan dengan pembelajaran konvensional. Tahapan analisis data kuantitatif akan menggunakan metode statistik yaitu uji beda (t) dengan bantuan SPSS versi 20.

Tahapan analisis data kuantitatif dengan menggunakan statistik dilakukan dengan beberapa tahapan. Tahapan-tahapan tersebut adalah (1) analisis data deskriptif, (2) analisis uji normalitas dan homogenitas, (3) analisis uji beda dengan menggunakan uji t.

Langkah akhir dari pengolahan data, yaitu data n-gain yang berfungsi untuk mengetahui mutu peningkatan kemampuan berpikir kritis menggunakan bahan ajar berbasis quantum teaching.

\section{HASIL DAN PEMBAHASAN}

Tahapan pelaksanaan penelitian diawali dengan pengembangan produk bahan ajar berbasis berbasis model quantum teaching, selanjutnya produk bahan ajar diuji keefektifannya untuk meningkatkan kemampuan berpikir kritis siswa dengan metode kuasi eksperimen pada kelas eksperimen dan kelas kontrol.

\section{Pengembangan Produk Bahan Ajar}

Pengembangan produk bahan ajar berbasis model quantum teaching didasarkan pada modifikasi dari prosedur Borg \& Gall dengan tahapan (1) studi pendahuluan, (2) perencanaan, (3) desain produk, (4) validasi produk, (5) uji coba produk, dan (6) produk akhir.

Pertimbangan yang mendasari penggunaan model pengembangan Borg \& Gall yaitu (1) model ini diawali dengan analisis kebutuhan. Analisis kebutuhan pada penelitian ini menggunakan siswa. Diharapkan produk yang dihasilkan adalah produk yang sesuai dengan kebutuhan siswa sebagai pengguna produk; dan (2) model pengembangan ini memiliki tahapan-tahapan yang rinci dan sesuai untuk mengembangkan suatu produk tertentu serta dapat menjawab masalah-masalah dalam pembelajaran.

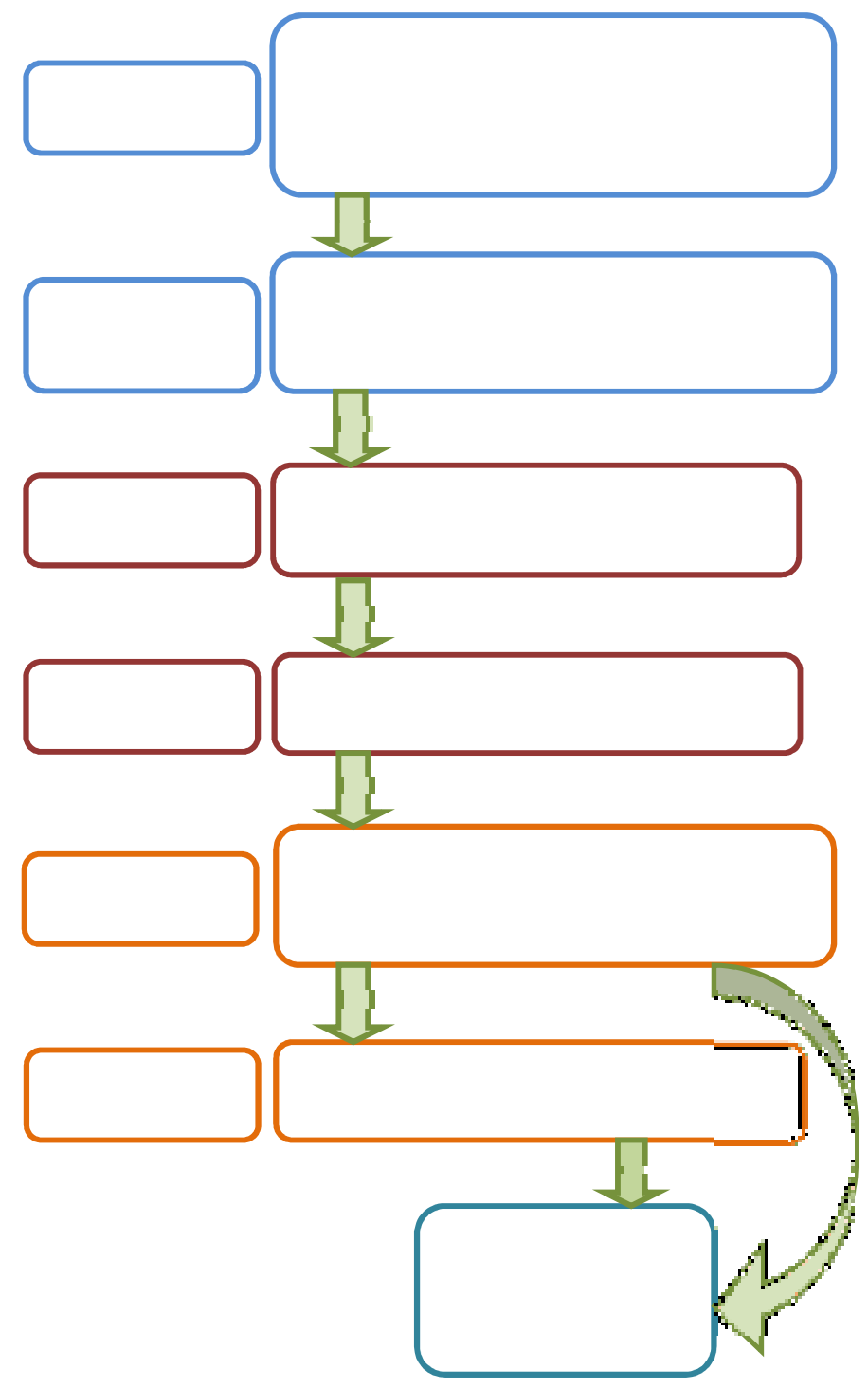

Gambar 2. Prosedur Penelitian Pengembangan (Diadaptasi dari Sugiyono (2010: 434)

Hasil Penelitian dan pengembangan berupa produk buku bahan ajar berbasis model quantum teaching untuk meningkatkan kemampuan berpikir kritis untuk siswa yang telah valid dan praktis digunakan. Hasil uji validasi ahli yaitu $86,45 \%$ dengan kategori sangat valid. Hasil uji keterbacaan bahan ajar sebesar 88. Hasil uji kepraktisan respons siswa terhadap bahan ajar sangat praktis dengan persentase $86,57 \%$. Contoh produk bahan ajar berbasis model quantum teaching disajikan pada Gambar 2. 


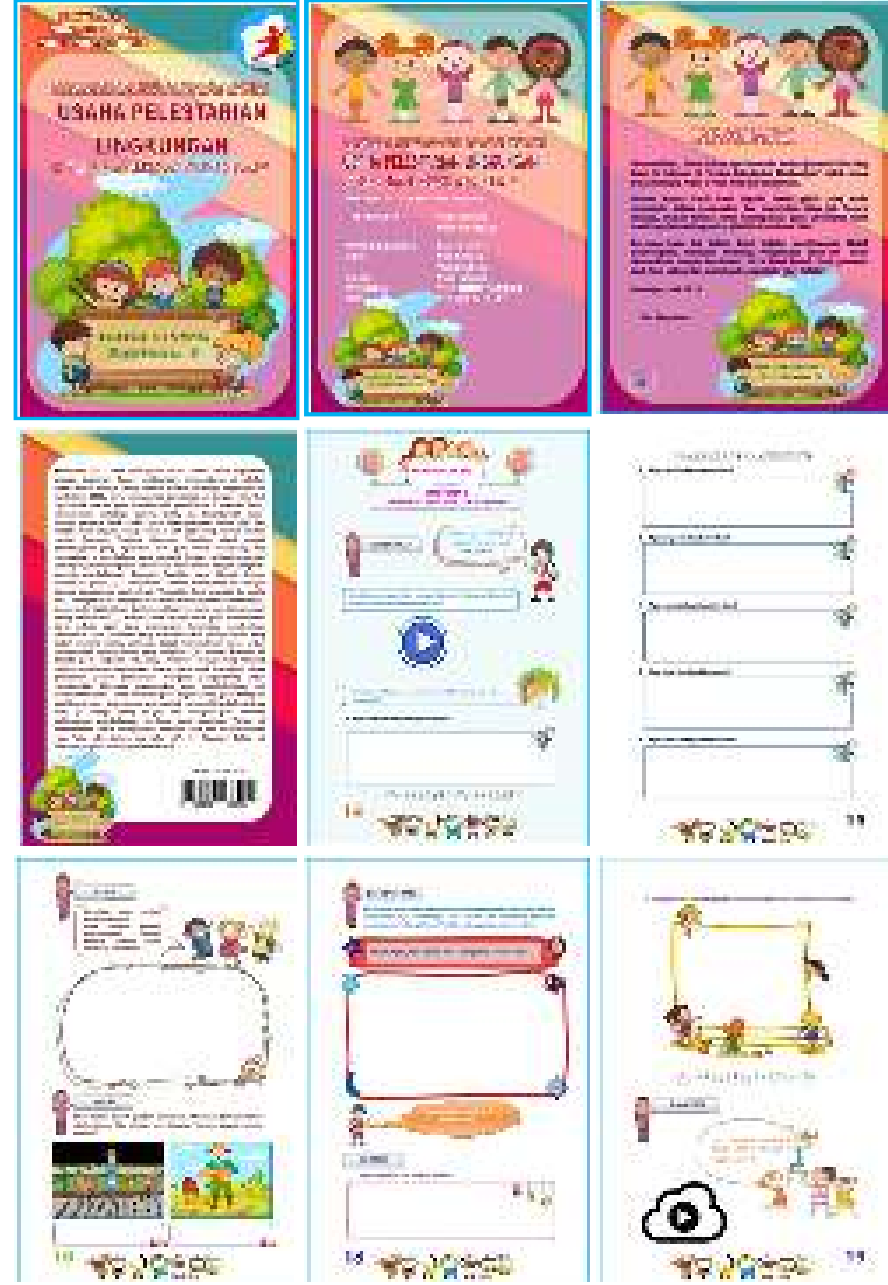

Gambar 3. Contoh Isi Produk Akhir

Bahan Ajar Buku Siswa

(Sumber: Dokumentasi Peneliti, 2019)

\section{Pelaksanaan Penelitian}

Pelaksanaan penelitian dilakukan dalam enam kali pertemuan pembelajaran baik pada kelas kontrol maupun kelas eksperimen. Materi dan tahapan kegiatan dimodifikasi dengan model pembelajaran quantum teaching. Setiap pertemuan dilaksanakan dalam satu hari kegiatan pembelajaran dan mencakup seluruh mata pelajaran sesuai jadwal pembelajaran di sekolah. Produk bahan ajar buku siswa hanya digunakan pada kelas eksperimen, sementara kelas kontrol menggunakan buku guru dan buku siswa yang telah ada sebelumnya di sekolah. Tahapan pembelajaran mencakup pra kegiatan, kegiatan inti dan kegiatan akhir.

\section{Analisis Data dan Pembahasan}

Dalam penelitian ini, untuk mengetahui kemampuan berpikir kritis siswa dilakukan dengan memberikan tes kepada siswa pada kedua kelas. Data tersebut berupa skor pretes dan skor pascates dari kelas eksperimen dan kelas kontrol. Data hasil prates dan pascates kemampuan berpikir kritis siswa tersebut selengkapnya dapat dilihat pada tabel berikut ini.

Tabel 2. Deskripsi Hasil Prates dan Pascates Kemampuan Berpikir Kritis

\begin{tabular}{|l|c|c|c|c|}
\hline \multirow{2}{*}{ Subjek } & \multicolumn{2}{c|}{ Kelas Eksperimen } & \multicolumn{2}{c|}{ Kelas Kontrol } \\
\cline { 2 - 5 } & Prates & Pascates & Prates & Pascates \\
\hline Median & 8 & 12 & 8 & 10 \\
\hline Modus & 7 & 12 & 8 & 10 \\
\hline $\begin{array}{l}\text { Standar } \\
\text { Deviasi }\end{array}$ & 1,988 & 1,713 & 1,979 & 1,783 \\
\hline Varians & 3,952 & 2,935 & 3,916 & 3,179 \\
\hline Range & 7 & 6 & 7 & 7 \\
\hline $\begin{array}{l}\text { Nilai } \\
\text { Minimum }\end{array}$ & 5 & 9 & 5 & 6 \\
\hline $\begin{array}{l}\text { Nilai } \\
\text { Maksimum }\end{array}$ & 12 & 15 & 12 & 13 \\
\hline Mean & 7,78 & 11,81 & 7,97 & 9,35 \\
\hline \multicolumn{5}{|c|}{ Nilai Maksimum Ideal $=15$} \\
\hline
\end{tabular}

Dari tabel di atas diketahui rata-rata nilai pretest kelas eksperimen adalah 7,78 dan ratarata nilai postes kelas eksperimen adalah 11,81. Sedangkan Rata-rata nilai pretest kelas kontrol adalah 7,97 dan rata-rata nilai postes kelas kontrol adalah 9,35.

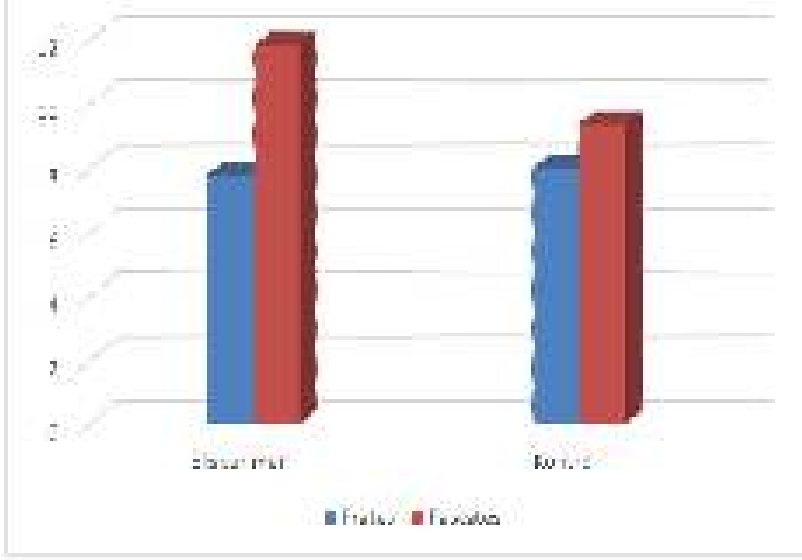

Gambar 4. Hasil Prates dan Pascates Kemampuan berpikir kritis pada Kelas Eksperimen dan Kelas Kontrol

Setelah didapat hasil prates dan pascates kemampuan berpikir kritis pada kelas eksperimen dan kelas kontrol, selanjutnya dilakukan uji normalitas dan uji homogenitas. Hasilnya didapat seperti dijelaskan tabel 4 dan 5 di bawah ini.

Tabel 4. Uji Normalitas Data Prates dan Pascates Kemampuan Berpikir Kritis 


\begin{tabular}{|l|c|c|c|c|}
\hline \multirow{2}{*}{ Data } & \multirow{2}{*}{ Kelas } & \multicolumn{2}{|c|}{ Shapiro-Wilk } & \multirow{2}{*}{ Kesimpulan } \\
\cline { 3 - 4 } & & $\mathbf{S i g}$ & $\boldsymbol{\alpha}$ & \\
\hline \multirow{2}{*}{ Skor Pretes } & \multirow{2}{*}{ Eksperimen } & 0,053 & 0,05 & Normal \\
\cline { 3 - 5 } & & 0,073 & 0,05 & Normal \\
\hline Skor Pascates & & 0,083 & 0,05 & Normal \\
\hline Skor Pretes & \multirow{2}{*}{ Kontrol } & 0,140 & 0,05 & Normal \\
\hline \multicolumn{2}{|l|}{ Skor Pascates } & & 0,140 & \multicolumn{3}{|c}{} \\
\hline
\end{tabular}

Melalui data tersebut, maka untuk uji komparasi prates maupun pasca tes Kemampuan Berpikir Kritis menggunakan uji-t. Hal tersebut dikarenakan data kelas eksperimen berdistribusi normal dan kelas kontrol juga berdistribusi normal. Sehingga data tersebut perlu dilakukan uji homogenitas.

Tabel 4 Uji Homogenitas Data Prates dan Pascates Kemampuan Berpikir Kritis

\begin{tabular}{|c|l|c|c|l|}
\hline \multirow{2}{*}{ Data } & \multirow{2}{*}{ Kelas } & \multicolumn{2}{|c|}{ Levene } & \multirow{2}{*}{ Kesimpulan } \\
\cline { 3 - 4 } & & Sig & $\boldsymbol{\alpha}$ & \\
\hline \multirow{2}{*}{ Prates } & Eksperimen & \multirow{2}{*}{0,916} & 0,05 & \multirow{2}{*}{ Homogen } \\
\cline { 2 - 3 } & Kontrol & & \\
\hline \multirow{2}{*}{ Pascates } & Eksperimen & 0,935 & 0,05 & \multirow{2}{*}{ Homogen } \\
\cline { 2 - 2 } & Kontrol & & \\
\hline
\end{tabular}

Setelah dilakukan uji normalitas dan uji homogenitas terhadap data prates dan pascates kemampuan berpikir kritis siswa pada kelas eksperimen dan kontrol, langkah selanjutnya adalah melakukan uji perbedaan menggunakan Analisis Independent Samples T Test.

Tabel 5. Uji t Data Prates dan Pascates Kemampuan Berpikir Kritis Kelas Eksperimen dan Kontrol

\begin{tabular}{|l|c|c|c|c|}
\hline \multicolumn{1}{|c|}{ Data } & $\mathbf{t}_{\text {hitung }}$ & Df/t tabel & $\begin{array}{c}\text { Sig. (2- } \\
\text { tailed) }\end{array}$ & Kesimpulan \\
\hline $\begin{array}{l}\text { Pretest Kelas } \\
\text { Eksperimen } \\
\text { dan Kontrol }\end{array}$ & 0,410 & $72 / 1,994$ & 0,683 & $\begin{array}{c}\text { Tidak } \\
\text { terdapat } \\
\text { perbedaan }\end{array}$ \\
\hline $\begin{array}{l}\text { Posttest Kelas } \\
\text { Eksperimen } \\
\text { dan Kontrol }\end{array}$ & 6,050 & $72 / 1,994$ & 0,000 & $\begin{array}{c}\text { Terdapat } \\
\text { perbedaan }\end{array}$ \\
\hline
\end{tabular}

Selanjutnya dilakukan uji gain dengan tujuan mencari selisih antara nilai posttest dan pretest. Hasilnya dapat dilihat pada tabel di bawah ini.

Tabel 6. Hasil Uji Gain kemampuan berpikir kritis siswa kelas eksperimen dan kelas kontrol

\begin{tabular}{|c|l|c|c|c|}
\hline \multirow{2}{*}{ Kelas } & \multirow{2}{*}{ Kemampuan } & \multicolumn{2}{|c|}{ Skor } & \multirow{2}{*}{ Kriteria } \\
\cline { 3 - 4 } & berpikir kritis & Rata-rata & N-gain & \\
\hline \multirow{2}{*}{ Eksperimen } & Prates & 7,78 & \multirow{2}{*}{0,59} & \multirow{2}{*}{ Sedang } \\
\cline { 2 - 3 } & Pascates & 11,81 & & \\
\hline \multirow{2}{*}{ Kontrol } & Prates & 7,97 & \multirow{2}{*}{0,20} & \multirow{2}{*}{ Rendah } \\
\cline { 2 - 3 } & Pascates & 9,35 & & \\
\hline
\end{tabular}

Berdasarkan tabel diatas dapat diinterpretasikan bahwa skor rata-rata pretes kemampuan berpikir kritis siswa pada kelas eksperimen sebesar 7,78 dan hasil pascates sebesar 11,81. Dari data tersebut diperoleh Ngain sebesar 0,59. Maka N-gain pada kelas eksperimen termasuk kedalam kriteria "Sedang". Pada kelas kontrol dapat dilihat bahwa skor rata-rata pretes kemampuan berpikir kritis siswa sebesar 7,97 dan skor pascates sebesar 9,35. Sehingga diperoleh $\mathrm{N}$-gain sebesar 0,20 Maka dapat disimpulkan bahwa $\mathrm{N}$-gain pada kelas kontrol termasuk ke dalam kriteria "Rendah".

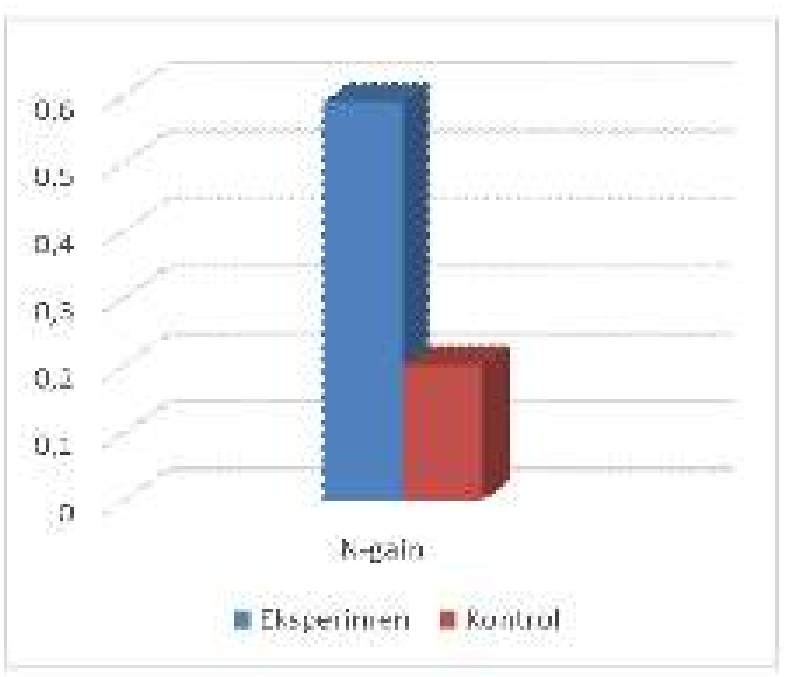

Gambar 5. Hasil Uji Gain kemampuan berpikir kritis siswa pada kelas eksperimen dan kontrol

Untuk melihat gambaran hasil uji gain kemampuan berpikir kritis siswa antara kelas eksperimen dengan kelas kontrol secara individu dapat dilihat pada grafik berikut ini.

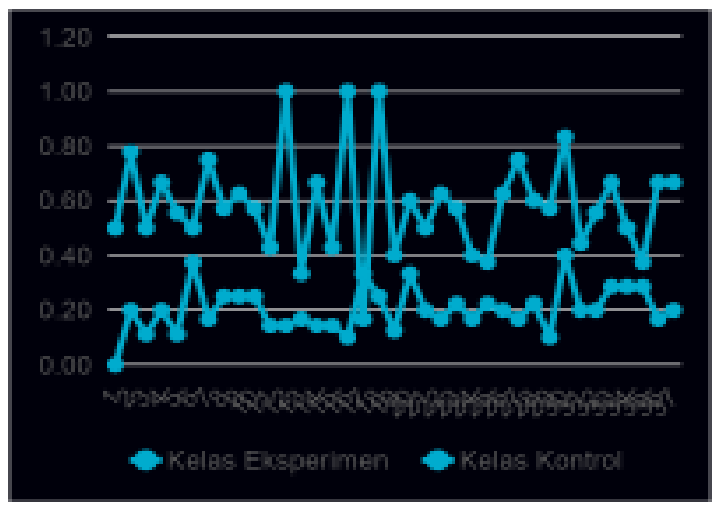

Gambar 6. Hasil Uji Gain kemampuan berpikir kritis siswa pada kelas eksperimen dan kontrol secara individu

Berdasarkan hasil analisis data dapat diketahui bahwa Bahan Ajar Berbasis model 
quantum teaching efektif dalam meningkatkan kemampuan berpikir kritis. Peningkatan tersebut terlihat dari nilai pretes dan postes kelas eksperimen. Selain itu mutu peningkatan juga dapat ditunjukkan dari nilai gain yang tinggi.

Model pembelajaran quantum teaching dikatakan lebih baik karena dalam pelaksanaan pembelajarannya peserta didik terlibat dalam pembelajaran dan aktif bekerja sama dalam memahami materi melalui bahan ajar serta dalam menyelesaikan setiap permasalahan (Santoso, 2016:67). Hal tersebut terjadi karena mereka merasa nyaman dan senang untuk belajar. Hal ini sesuai dengan tujuan pembelajaran Quantum menurut Porter, Bobbi De, dan Mike Hernacki (2013) yang berupaya menciptakan suasana belajar yang nyaman dan menyenangkan.

Pengembangan bahan ajar membuat peserta didik terlatih untuk memecahkan masalah dan membangun sendiri pengetahuannya. Hal ini sejalan dengan teori Piaget (Ruseffendi, E.T, 2006 :133) bahwa pembelajaran sebagai proses yang aktif artinya pengetahuan baru tidak diberikan kepada siswa dalam bentuk jadi tetapi siswa membentuk sendiri pengetahuannya.

\section{SIMPULAN}

Sesuai dengan tahapan pelaksanaan kegiatan penelitian, maka peneliti dapat mengambil kesimpulan sebagai berikut.

Terdapat peningkatan kemampuan berpikir kritis peserta didik yang menggunakan bahan ajar berbasis model Quantum Teaching dibandingkan dengan peserta didik yang menggunakan pembelajaran konvensional. Peningkatan ini terlihat dari deskripsi data hasil pretest kelas kontrol dan eksperimen, juga deskripsi data hasil postes kelas kontrol dan eksperimen.

Terdapat perbedaan peningkatan kemampuan berpikir kritis peserta didik yang menggunakan bahan ajar berbasis model model Quantum Teaching jika dibandingkan dengan peserta didik yang tidak menggunakan bahan ajar dan dengan pembelajaran konvensional. Perbedaan peningkatan ini dapat dilihat pada hasil uji gain kemampuan berpikir kritis siswa pada kelas eksperimen menunjukkan $\mathrm{N}$-gain sebesar 0,59. Maka N-gain pada kelas eksperimen termasuk ke dalam kriteria "Sedang". Sedangkan hasil uji gain kemampuan berpikir kritis siswa pada kelas kontrol diperoleh Ngain sebesar 0,20. Maka N-gain pada kelas kontrol termasuk ke dalam kriteria "Rendah".

\section{SARAN}

Berdasarkan rangkaian kegiatan penelitian
yang telah dilaksanakan, peneliti
mengemukakan saran sebagai berikut.

Bahan ajar berbasis model quantum teaching merupakan alternatif pengembangan bahan ajar dan model pembelajaran yang dapat digunakan oleh guru kelas untuk meningkatkan kemampuan berpikir kritis pada siswa kelas V di Kabupaten Kuningan.

Bahan ajar berbasis model quantum teaching pada penelitian ini menunjukkan hasil yang efektif karena digunakan dalam pembelajaran yang mendukung untuk digunakannya bahan ajar dan model pembelajaran tersebut. Bagi peneliti selanjutnya, dapat mengkaji kembali keefektifan bahan ajar berbasis model quantum teaching dalam aspek keterampilan atau kemampuan lain dengan lebih luas dan lebih mendalam.

\section{DAFTAR PUSTAKA}

Amalia, Nur Fitri dan Pujiastuti, Emi. 2016. Kemampuan Berpikir Kritis dan Rasa Ingin Tahu Melalui Model PBL. Seminar Nasional Matematika X Universitas Negeri Semarang 2016. ISSN 2613-9189.

Ary, D., Jacobs, L. C \& Sorensen, C. K. 2010. Introduction to research in education eighth edition. Wadsworth: Cengage Learning.

DePorter, Bobbi. 2011. Quantum Teaching: Mempraktikkan Quantum Learning di Ruang-Ruang Kelas. Bandung: Kaifa Learning.

DePorter, Bobbi dan Hernacki, Mike. 2013. Quantum Learning: Membiasakan Belajar Nyaman dan Menyenangkan. Bandung: Kaifa Learning.

Filsaime. 2008. Menguak Rahasia Berpikir Kritis dan Kreatif. Jakarta: Prestasi Pustakarya

Hartini, Ayu. 2017. Pengembangan Perangkat Pembelajaran Model Project Based Learning untuk Meningkatkan Kemampuan Berpikir Kritis Siswa Sekolah Dasar. ELSE (Elementary School Education Journal): Jurnal Pendidikan dan Pembelajaran Sekolah Dasar Volume 1 
Nomor 2a Desember 2017 E-ISSN: 25974122.

Hendrawan, Budi. (2016). Hubungan Antara Pengelolaan Kondisi Sosio Emosional dan Prestasi Belajar Siswa Pada Pembelajaran IPA Di Kelas V Sekolah Dasar. Naturalistic: Jurnal Kajian Penelitian Pendidikan dan Pembelajaran Vol. 1 No. 1, 2016, ISSN : 2528-2921.

Hughes, C. 2014. Theory of Knowledge aims, objectives and assessment criteria: An analysis of critical thinking descriptors. Journal of Research in International Education 2014 Vol. 13(1) 30: sagepub.co.uk/journalspermissions.nav.

Kaddoura. 2009. .New Graduate Nurses" Perception of Critical Thinking Development in Critical Care Nursing Training Programs. Dissertation Health Professions Education.

Kettler. 2014 Critical Thinking Skills Among Elementary School Students: Comparing Identified Gifted and General Education Student Performance. Gifted Child Quarterly 2014, Vol. 58(2) 127-136: sagepub.com/journalsPermissions.nav.

Khairani, Annisa Laras. dkk. 2016. Pengaruh Model Pembelajaran Quantum Teaching tipe TANDUR diintegrasikan dengan Kartu Tangram terhadap Hasil Belajar Matematika Siswa. FIBONACCI: Jurnal Pendidikan Matematika \& Matematika Volume 2 Nomor 1 Juli 2016

Nugraha, Widdy Sukma. 2018. Peningkatan Kemampuan Berpikir Kritis dan Penguasaan Konsep IPA Siswa SD dengan Menggunakan Model Problem Based Learning. EduHumaniora: Jurnal Pendidikan Dasar $\mid \mathrm{p}$ ISSN 2085-1243 | e-ISSN 2579-5457 Vol. 10 No.2 Juli 2018 | Hal 115-127.

Perwitasari, Suci. dkk. 2018. Pengembangan Bahan Ajar Tematik Berbasis Kontekstual. Jurnal Pendidikan: Teori, Penelitian, dan Pengembangan Volume: 3 Nomor: 3 Bulan Maret Tahun 2018

Rahayu, Sinta. dkk. 2014. Pengaruh Model Quantum Teaching terhadap Hasil Belajar dalam Pembelajaran Tematik di Sekolah
Dasar. Jurnal Pedadidaktika: Jurnal Ilmiah Pendidikan Guru Sekolah Dasar, ISSN 2406-8705.

Russeffendi, E.T. 2006. Dasar-dasar Penelitian Pendidikan dan Bidang Non-Eksakta Lainnya. Bandung : Tarsito.

Santoso, Erik. 2016. Pengaruh Penggunaan Model Pembelajaran Quantum terhadap Kemampuan Berpikir Kritis Matematik Peserta Didik (Studi Eksperimen di Kelas $V$ SDN Gununglipung Kota Tasikmalaya Tahun Pelajaran 2015/2016). Jurnal Cakrawala Pendas, Vol. 2, NO. 1 Januari 2016 ISSN: 2442-7470.

Sugiyono. 2010. Metode Penelitian Pendidikan. Bandung: Alfabeta

Suparmono, Agus. 2016. Pengaruh Model Pembelajaran Quantum (Quantum Teaching) terhadap Hasil Belajar IPA Siswa Kelas III SD YPS Lawewu Kecamatan Nuha Kabupaten Luwu Timur. Jurnal Nalar Pendidikan Volume 4, Nomor 2, Jul-Des 2016.

Tinja, Yasintus. dkk. 2017. Pengembangan Bahan Ajar Tematik Berbasis Kearifan Lokal sebagai Upaya Melestarikan Nilai Budaya pada Siswa Sekolah Dasar. Jurnal Pendidikan: Teori, Penelitian, dan Pengembangan Volume: 2 Nomor: 9 Bulan September Tahun 2017.

Wibowo, Roni. dkk. 2017. Bahan Ajar Tematik Materi Puisi Kelas $V$ SD dengan Pemanfaatan Peta Pikiran dan Lingkungan Sekitar. Jurnal Pendidikan: Teori, Penelitian, dan Pengembangan Volume: 2 Nomor: 6 Bulan Juni Tahun 2017.

Yahya, Husniati. 2017. Pengaruh Penerapan Model Pembelajaran Quantum Teaching terhadap Hasil Belajar Biologi Siswa SMP Islam Terpadu Al-Fityan Gowa. Jurnal Biotek Jurusan Pendidikan Biologi Fakultas Tarbiyah dan Keguruan UIN Alauddin Makassar Volume 5 Nomor 1 Juni 2017 ISSN Print: 2354-9106 ISSN Online: 2581-1827. 